find a home either within the new office devoted to Mission to Planet Earth or fall under the programme for planetary science and astrophysics, the two successors to the space science and applications office that Fisk has led since 1987.

Fisk, having lost control of a \$2-billion programme, has been assigned to the administrator's office as the agency's first chief scientist. At a press conference on 15 October, Fisk said that his new position demonstrates science is vital to NASA, but it is more likely that Fisk has been kicked upstairs.

A familiar sight on Capitol Hill, Fisk gets on well with the congressional committees that oversee NASA. A former professor of physics at the University of New Hampshire, Fisk has won grudging support from researchers for his long-term plan for the agency's space science efforts. His office is responsible for such projects as the multibillion-dollar Earth Observing System (a constellation of satellites to monitor the environment), the Advanced X-Ray Astrophysics Facility to be launched later in the decade and the near-sighted Hubble Space Telescope.

In recent years, however, the White House National Space Council has been pressing NASA to buy the "cheaper, faster, better" approach favoured by the vice president, Dan Quayle. Fisk has been a reluctant supporter of the concept.

Goldin took office after Richard Truly was fired on 10 February for failing to follow Quayle's orders and immediately began pressing his managers to shrink their programmes. Goldin is eager to bring in his own team, and removing Fisk sees a natural step in that process.

The pieces of the old science office fall - at least temporarily - to Shelby Tilford, director of Earth sciences, and Wes Huntress, director of Solar Systems exploration. But Goldin promised last week to allow other NASA employees and outsiders to compete for those two jobs and a host of others. The move could also lower barriers to cooperation with the Defense and Energy departments, whose scientists now want to use sophisticated sensors designed for the Cold War for civilian missions.

Another victim of the reorganization is the office of aeronautics and space technology. Its head, Pete Peterson, has been asked to conduct a long-term study of US aeronautics and space facilities, while Cecil Rosen, who was aeronautics director, takes over as acting chief of a strengthened aeronautics office.

Goldin has transformed the space technology portion of the agency into an advanced concepts office run by Gregory Reck that will also include the agency's commercial programmes. Courtney Stadd, formerly of the White House National Space Council, assumes the job of acting deputy associate administrator for the new office.

Andrew Lawler

\title{
Racial tensions entangle NIH in dispute over AIDS drug
}

Washington. Under pressure from the Nation of Islam and other AfricanAmerican activist and political groups, the National Institutes of Health (NIH) is reconsidering a report issued earlier this year rejecting Kemron and other interferon alpha-based drugs as useful treatments for people with AIDS. NIH officials concede that they were politically naive when they evaluated the drugs - often touted as an 'African AIDS cure' because some early clinical trials were conducted in Kenya - in the same way as any other experimental therapy without accounting for the desperation and suspicion of those affected by the AIDS epidemic.

Next week, advocates of oral interferon alpha will hold a long-awaited meeting with $\mathrm{NIH}$ officials as the first step towards NIHsponsored clinical trials of the drug for those with AIDS. But even this is fraught with racial tensions. Because many AfricanAmerican groups believe that the government is ignoring - or even encouraging the problem of AIDS within minority populations, NIH asked the National Medical Association (NMA), an organization comprised mostly of African-American physicians, to invite the participants and serve as the host. Yet in the same week that invitations were sent out, NIH mailed to NMA members a copy of its April report rejecting interferon alpha as a treatment for AIDS. Advocates of the drug accuse NIH of trying to prejudice the debate; NIH says that it was simply trying to disseminate relevant information to all those interested.

The agendas of the participants reflect the distance separating them: advocates of interferon alpha, who have been selling and distributing the drug to AIDS patients for more than a year, want NIH to evaluate their clinical data and sponsor more formal clinical trials, while $\mathrm{NIH}$ officials, including
Daniel Hoth, director of the NIH division of AIDS, have taken the position that they first need to learn more about the claims being made for the drug. However, NIH has agreed to examine some new data and conduct another assessment of interferon alpha to supersede its earlier report. And last month the Congressional Black Caucus, a group of African-American legislators, met NIH officials and argued the case for Kemron.

Various claims have been made for the efficacy of low-dose oral interferon alpha in treating AIDS. After the initial 1989 clinical trial in Kenya, Davy Koech, director of the Kenyan Medical Research Institute, reported that $\mathrm{CD} 4$ counts had improved substantially in many of the participants and that as many as 20 per cent had become HIV-seronegative. These results created a worldwide demand. However, since then even Koech has played down 'serodeconversion' (which has not been replicated) as a measure of efficacy and has instead focused on such indicators as the level of symptoms and overall health, energy and appetite of the patients.

Although NIH continues to stand behind the April report (see Nature 356, 648; 1992), its conclusions have been rejected by many of the groups who use and prescribe the drugs. Advocates point out that NIH focused on the dramatic serodeconversion and CD4 claims, rather than the more subjective (and better replicated) reports of symptom reduction. Barbara Justice, a physician affiliated with the Nation of Islam who runs an AIDS clinic in New York, says that NIH also erred in favouring randomized and placebo-controlled clinical trials and immune system measures such as CD4 counts and should have focused instead on whether AIDS patients were healthier - by any measure - after interferon-alpha treatment. "NIH is hung up on 'double-

\section{NHS opens meta-analysis centre}

London. Britain's plan to coordinate and strengthen research by the National Health Service (NHS) takes an important step forward next month with the opening of a new centre for meta-analysis.

The Cochrane Centre in Oxford will compile and systematically review clinical and other randomised controlled trials on topics from drugs to surgical instruments. It will also help researchers to perform metaanalyses or overviews of specialist areas with the goal of making the data available to clinicians. The creation of the centre, with an annual budget of $£ 300,000$, indicates the increasing importance of meta-analysis in interpreting clinical trials and is a response to criticism that the results are implemented slowly and inconsistently. The NHS is planning another facility for reviewing work other than randomized controlled trials and has already created a database that, for the first time, gives a clear picture of the amount and nature of research going on in the NHS.

Next month, the NHS is also expected to complete the hiring of 14 regional research and development directors responsible for implementing the new research strategy. The NHS has promised to spend 1.5 per cent of its budget on research by 1997 , around $£ 375$ million at today's prices.
Ian Mundell 


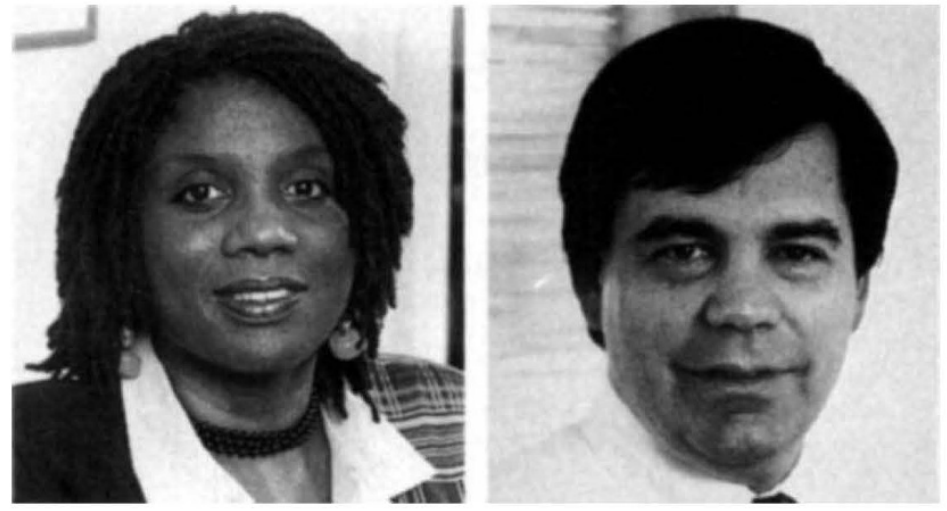

African-American doctors like Barbara Justice (left) have stepped up pressure on Daniel Hoth (right) and other NIH officials for government-sponsored clinical trials of interferon alpha.
The twisted

history of

Kemron and a host of similar interferonalpha-based products contributes to the confusion. Int e r f e r o n alpha therapy was developed 20 years ago by Joseph Cummins, a Texas veterinary microbiologist and president of the Amarillo

blind this' and 'T-Cell that" ", she says. "I'm hung up on my patients getting better."

Her argument reflects the problem of applying the usual methods of scientific assessment to an issue in which there is great hostility towards the government. NIH sponsored the analysis because it felt it had a public health obligation to determine if an unapproved drug being used by thousands of people actually worked. Yet when NIH concluded that it did not, it is not surprising that the agency failed to get that message across. The African-American groups who see interferon alpha as a African solution to the AIDS problem were not persuaded to drop their efforts by a government report that, to them, was based on obscure scientific standards rather than real experience. And some errors in the NIH report, including aggregating incompatible trials, fuelled suspicions that the US government was trying to suppress the drug.
Cell Culture Co. Inc, as a treatment for respiratory disease in cattle. Cummins has conducted clinical trials of interferon, with varying success, on a number of human and animal diseases. Earlier this year, he received approval for interferon-alpha clinical trials on AIDS patients in the United States.

In 1989, Cummins travelled to Kenya to test interferon alpha in cattle diseases. $\mathrm{He}$ met Koech, who was studying AIDS therapies and had seen a 1986 paper by Cummins on the use of low-dose interferon alpha to treat feline leukaemia, a disease that is related to AIDS. Cummins showed Koech data from a trial he had started the previous year in Texas of interferon on HIV-positive patients. He then provided Koech with interferon-alpha powder from Japan and Koech began uncontrolled clinical trials on Kenyan AIDS patients. After a few weeks Koech reported dramatic improvements, and announced at a press conference that he had discovered a secret AIDS treatment he called KEO-89. In February 1990, he announced that the drug was oral interferon alpha and would be marketed as Kemron.

Hoping to replicate the results in a placebo-controlled trial, Cummins sent Koech interferon tablets in January 1990. But Koech decided that results were so promising that it would be unethical to withhold the drug from a placebo population.

The situation soon became chaotic. Cummins discovered that many of the interferon-alpha tablets - and the matching placebos - that he had shipped to Koech were instead being sold on the black market for as much as $\$ 50$ each.

Since then, Cummins' company has sued an Australian company for patent infringement after it began marketing a product called Immunex in Africa and the United States, and a US company, also called Immunex, has threatened to file a trademark infringement suit against the US importers. The result is that the drug will now sell in the United States as Immuviron, without FDA approval, at about $\$ 8$ a dose, nearly one hundred times the cost of production.

Advocates continue to use and prescribe oral interferon alpha, pointing out that, unlike accepted AIDS drugs such as AZT, it is nontoxic in low doses. Although it may not cure AIDS, they believe that it alleviates symptoms and want NIH to evaluate as it does other AIDS drugs - not as a cure, but as a therapy. Given the continuing demands for clinical trials from the hundreds of US AIDS patients being treated with interferon alpha who believe that their government is suppressing a promising treatment, NIH may find these arguments hard to resist.

Christopher Anderson

\section{NSF drops flat-rate plan for grants in mathematics}

Washington. A plan hastily conceived by the US National Science Foundation to award mathematics grants of a predetermined amount (see Nature 359, 94; 1992) has been withdrawn after complaints that it would not achieve the goal of funding more research. NSF had regarded the plan as a model for preserving the vitality of various disciplines without spending more by standardizing the size of grants and limiting the amount of overhead (so-called indirect costs) paid to universities for sponsoring research on campus.

Last May, NSF's mathematics advisory group asked the foundation to find a way to fund 100 or so more proposals each year despite a flat budget. The obvious solution was to reduce the size of existing grants by a small amount and to apply the money saved to new grants. By the end of August, NSF had a plan by which investigators would receive grants of either $\$ 20,000$ or $\$ 30,000$, depending on the quality of the research, and $\$ 10,000$ more for a graduate or postdoctoral student. Budgets would not be negotiated individually, and no allowances would be made for variations in indirect costs and other expenses.

NSF sent a letter to the mathematics community explaining the plan and announcing that it would take effect on 1 October. But officials soon discovered that researchers were not pleased with its work. "They screwed up, there's no other way to put it", says Jerry Bona, former chairman of the advisory committee and a mathematics professor at Pennsylvania State University.

One problem with the NSF plan was that it would not have funded any more grants. "We would have wound up raising some grants and cutting others drastically", says Bona, "but there would have been no new grants in the first two years." Another problem was the approach to indirect costs. By failing to recognize the wide variation in rates among research universities, set during annual negotiations with the government, NSF was ignoring existing federal policy and penalizing private universities, where costs are generally higher than at public universities.

After meeting the science policy committee of the American Mathematical Society in early September and hearing protests from the community, NSF decided to defer the plan. "NSF's policy is to pay the appropriate indirect costs and this project does not change that policy", says Judith Sunley, executive officer for the NSF directorate that includes mathematics and a former director of the division.

The mathematics advisory committee will discuss the issue at its meeting next week and is likely to ask NSF to devise a better plan. Sunley says that NSF hopes to have a new version ready by January, when Fred Wan of the University of Washington joins NSF as director of the mathematics division. Until then, NSF will continue its current policy of negotiating individual budgets for each grant.

Jeffrey Mervis 